\title{
University Archives: The Australian Scene
}

\section{Nessy Allen}

\begin{abstract}
A recent survey of the development and administration of archives in Australian universities reveals similarities with those in North America and difficulties for units in both regions. While many of the Australian archives have been developed according to the special needs of $a$ particular university and, in some cases, of the community it serves, they share with their United States and Canadian counterparts problems of finance, staffing, space allocation, placement, and management.
\end{abstract}

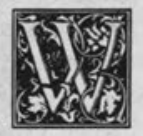

hen institutions of higher education decide to establish an archive, as opposed to simply accumulating records, they must make decisions about matters common to all organizations planning a similar move. Such decisions include the physical location of the archive and the allocation of space to meet immediate and future needs; the specific functions of the archive and whether it is to serve only as a repository of the institution's records or whether it will also hold the archives of other organizations; the management of the archive and whether it will come under the supervision of the central administration or that of the library; and the financing of the archive for both its establishment and its future development. Some of these issues, as well as more technical ones, have been discussed by others and various models for dealing with them have been proposed. ${ }^{1}$ Data of general interest are set out in this article to show how such matters have been handled by Australian universities in setting up their archives; where appropriate, comparison is made with North American patterns.

\section{DEVELOPMENT OF ARCHIVES AND THE UNIVERSITIES}

The Australian higher education system developed gradually. In 1956 there were only nine universities in Australia. As undergraduate student numbers grew, however, colleges of advanced vocational education were established and new universities were set up. By 1976 nineteen of the twenty-one Australian universities had been established. The two not considered here were upgraded from college status after this study was completed. In 1977 the commonwealth government brought all postsecondary education under the control of one body, the Tertiary Education Commission (later the Commonwealth Tertiary Education Commission, CTEC), which advised the government after consulting with its various advisory councils established for the different tertiary sectors. Although the recommendations of the commission were not necessarily accepted by the government, the commission put into effect the government's subsequent decisions.

Although the nomenclature of institutions is similar in North America and Australia in that both have colleges and universities, and although there are parallels, the two systems are not identical. Until 1987 , for example, there were no privately funded universities in Australia; and the status of an institution called a university was higher than that one called a college.

Nessy Allen is Lecturer at the School of Science and Technology Studies, University of New South Wales, P.O. Box 1, Kensington, 2033, N.S.W., Australia. 
In recent years pressure by the staff of colleges of advanced education has resulted in an upward trend, moving from college to university status; however, the first example since 1976 of such an upgrading occurred only in 1987.

The governance of higher education in Australia is clearly changing. In late 1987 the commonwealth government announced that CTEC was to be abolished and replaced by a Higher Education Council which will advise a National Board of Employment, Education, and Training. Soon afterwards the minister for employment, education, and training circulated a policy discussion paper on higher education which proposed the dismantling of the present binary system and the setting up of a unified national higher education system. The new system will affect not only existing archives and possibly their functions but also the establishment of any future archives.

As in the United States and Canada, the establishment of archives at Australian universities has been a relatively recent development, which began to gather momentum about thirty years ago. The first Australian university, the University of Sydney, was founded in 1850, followed shortly by the University of Melbourne in 1853. Appropriately enough, these two oldest universities were among the first to set up archives, albeit not until 100 years after their founding.

In the United States, Harvard University, although it began compiling and keeping records in 1851, did not set up an official archive on a statutory basis until $1939 .^{2}$ Only in the 1950 s and 1960 s did other universities and colleges in the United States begin their archival programs. ${ }^{3}$ A similar pattern emerged in Canada. Formal university archives were started there in the $1960 \mathrm{~s}$, when some of the older universities appointed professional archivists. ${ }^{4}$ In both countries, however, the rate of establishing archives has been relatively slow, and this is equally true of Australian universities.

Of the nineteen universities established in Australia by 1976, fifteen now have formal archives. The Australian National University (ANU), Griffith University,

\section{"Of the nineteen universities estab- lished in Australia by 1976, fifteen now have formal archives."'}

James Cook University, and Murdoch University have not yet begun archives, although they do, of course, keep university records. At all four of these archiveless universities there have been discussions about the establishment of archives.

The ANU is anomalous in that it keeps very extensive collections of business and trade union records. These collections were begun in the 1950 s by academics in various departments who were interested in materials for their research. Within a few years, an archives unit was started in the Research School of Social Sciences to house and develop these collections. ${ }^{5}$ The ANU administration keeps material related to the establishment of its various schools and private papers of eminent people connected with the university. In other words, archival material is being conserved. There is no move, however, to systematize all the holdings in a central archive, although the university is well aware of the need. A committee exists to consider the matter, but it has not met for some years, and while the university budget makes annual provision for one salary for archives, the amount is subsequently struck out as a savings measure. It is ironic that this university, the only one in Australia that has an abundance of space for records-a vast underground storage area-has not yet been able to set up an official archive.

Since the other three universities without archives are relatively new, they find that their present needs are met by central registry records. One of them, however, set up a working party which in 1985 recommended the establishment of an official archive. For financial reasons, the recommendation has not yet been adopted. In fact, given current economic trends, it appears unlikely that any of these universities will be able to establish archives in the near future. But institutions anxious to have archives should not despair: in the 
United States "one university waited forty-three years before a recommendation to establish an archive was acted on!"'6

The archives of the other fifteen universities were all established during the last 35 years. The first was in 1954; in the next decade, three more were set up; then five were established in the 1970 s and the other six in the 1980s (the last in 1986).

The data in this paper were collected by interview, in person or by telephone, with the most appropriate person. Generally this was the archivist, but in some cases it was the assistant vice-chancellor, the registrar, the deputy registrar, or the central records officer as well.

Table 1 shows the dates of foundation as autonomous bodies of the fifteen universities under discussion, together with the year in which their formal archives were established.

No obvious pattern of development emerges from table 1 . Appropriately, the oldest university in Australia was the first to establish an archive, followed by the second oldest. Interestingly, the third was a small regional university in New South Wales (New England), which established a unit only six years after its foundation. Two of the earliest and largest universities (Adelaide and Queensland) did not start their archives until the early 1980s, though of course they had been keeping records for many years. On the other hand, three of the newer universities (Monash, La

TABLE 1

FOUNDATION DATES OF UNIVERSITIES AND THEIR ARCHIVES

\begin{tabular}{lcc}
\hline \hline & University & Archive \\
\hline Sydney & 1850 & 1954 \\
Melbourne & 1853 & 1960 \\
Adelaide & 1874 & 1983 \\
Tasmania & 1890 & 1969 \\
Queensland & 1910 & 1982 \\
Western Australia & 1911 & 1979 \\
New South Wales & 1949 & 1980 \\
New England & 1954 & 1960 \\
Monash & 1958 & 1976 \\
La Trobe & 1964 & 1982 \\
Macquarie & 1964 & 1978 \\
Newcastle & 1965 & 1975 \\
Flinders & 1966 & 1986 \\
Deakin & 1974 & 1983 \\
Wollongong & 1975 & 1969 \\
\hline
\end{tabular}

Trobe, and Macquarie) established their archives within a relatively few years of their foundation, as did another (Newcastle) which had begun life as a university college. The last university to be founded (Wollongong) began its archive even before it became an autonomous university.

For the purposes of this paper, "old" universities are those founded before World War II. The "large" universities are Adelaide, Melbourne, Monash, New South Wales, Queensland, and Sydney, each of which has student numbers exceeding 13,000. Data are presented for old versus new and large versus small universities to determine to what extent, if any, age and size have influenced archival development. See table 2 .

Archival needs cannot always be met by the number of staff universities are able to provide. Four of the fifteen universities (27 percent) do not have a full-time archivist but have a person who works between half- and four-fifths time. Of the others, six ( 40 percent) have a full-time archivist, two have in addition an archivist/assistant, and another two have extra part-time assistance. The remaining institution, the University of Melbourne, with seven staff members, is a special case. The University of Melbourne followed the example of ANU and began a program of collecting business records; at Melbourne, however, the success of the program stimulated the creation of the university's official archive. Because of the extent of the support it receives from the business community, Melbourne's unit has the most sophisticated facility of any in Australia, as well as having a bigger staff than any other university's. Ian Wilson stated in 1977 that, in some Canadian universities, "the archival programme can be viewed as an extension of the archivist's personality. ${ }^{17}$ This is certainly true of Melbourne, which owes

TABLE 2

STAFFING OF ARCHIVES

\begin{tabular}{ccccc}
\hline \hline & \multicolumn{4}{c}{ Type of University } \\
& Large & Small & Old & New \\
\hline $\begin{array}{c}\text { One or more full-time } \\
\text { members of staff }\end{array}$ & 5 & 6 & 5 & 6 \\
$\begin{array}{c}\text { Less than one full-time } \\
\text { member of staff }\end{array}$ & 1 & 3 & 1 & 3 \\
\hline
\end{tabular}


much to the vision and energy of its first archivist.

Three of the university archivists are not professionally trained; that is, they do not hold formal archival qualifications. This seems to be due partly to the relatively recent introduction of formal training programs and partly to historical accident. One university archive, for instance, was set up because of the enthusiasm and determination of a particular staff member who was not appointed for the purpose but who had a sympathetic administration.

Again, the Australian situation regarding staffing is comparable to that existing in North America where several surveys of college and university archives have been undertaken. The most recent survey deals with the United States in the early $1980 \mathrm{~s}^{8}{ }^{8}$ The authors found that 30 percent of public institutions had no professional archival staff and that nearly the same percentage had only one full-time professional person. They compared their findings with those of a 1980 Canadian survey and identified a similar pattern there.

A leading archivist in the United States recommends the establishment in universities and colleges of an archives committee which, he says, "can be a valuable tool in educating faculty, students, and administrators to the role of an archives. ${ }^{\prime \prime 9}$ It is doubtful whether archives committees in Australian universities serve this role. Nevertheless, at all the universities that have such a committee, the archivists have indicated that they find its advice and guidance useful. In the same context, another U.S. author advocates that the committee be formed because it can give special help in obtaining an adequate archival budget. ${ }^{10}$

As can be seen from table 3, only six of Australia's universities have an archives committee; one of these, however, exists only in name, as it has never met. Of the others, two meet at irregular and infrequent intervals and the remainder meet between two and four times per year. At a seventh university, it is expected that a committee will be established in 1988 . Membership on committees varies from
TABLE 3

UNIVERSITIES THAT HAVE AN ARCHIVES COMMITTEE

\begin{tabular}{lcccc}
\hline \hline & \multicolumn{4}{c}{ Type of University } \\
& Large & Small & Old & New \\
\hline Committee & 2 & 4 & 2 & 4 \\
No committee & 4 & 5 & 4 & 5 \\
\hline
\end{tabular}

five to eight. One committee, that of an archive with external commitments, has fourteen members, including four from outside the university. Given the general irregularity of meetings, it is unlikely that the few committees in Australia are influential in attracting funds; no archivist referred to a committee's having played any role in obtaining financial support.

\section{FINANCES}

Restricted finances are a major problem for all university archivists. In the United States, the level of funding varies greatly, depending on whether the institution is public or private and whether it is large or small. Large public institutions are funded much more adequately than small private ones. ${ }^{11}$ Wilson reports that the financial problems of Canadian university archives are exacerbated when the archive is administratively located in the library. ${ }^{12}$ For reasons of confidentiality, not all Australian archivists were able to talk about their budgets but it was clear that, with only a few exceptions, archives are not funded generously. See table 4.

The archives at seven of the fifteen universities surveyed receive a separate budget, though this statement requires qualification. In only two cases does the budget cover both salaries and materials; one archive is funded for salaries only and four are funded for materials only, in one instance just a few hundred dollars per year.

TABLE 4

ARCHIVES RECEIVING EARMARKED FUNDING

\begin{tabular}{lcccc}
\hline \hline & & \multicolumn{2}{c}{ Type of University } \\
& Large & Small & Old & New \\
\hline Yes & 3 & 4 & 3 & 4 \\
No & 3 & 5 & 3 & 5 \\
\hline
\end{tabular}




\section{SPACE}

Lack of space was the greatest problem reported by all North American archival institutions. ${ }^{13}$ No Australian archivist considered that the space at his or her disposal was adequate; although, of course, the statement is difficult to interpret consistently unless a definition of adequate is given. See table 5. Some Australian archivists stated that they are able to make do by weeding. One reported that only the refusal, because of lack of staff, to accept much of the material offered made the available space adequate. Comparisons are difficult because of the differences between archives in the range of materials being collected and the length of time for which they have been collected. Nevertheless, it can be stated that, at present, the space of eight of the archives is adequate; that is, there is provision at least for the immediate future. The space available to two archives is only just adequate. For another two it is not adequate, but the situation will improve with the allocation of new or extended space within a year or so. The space given to the other three archives is inadequate. In fact, from this author's personal observation, it is ludicrously inadequate, and there is no prospect of improvement for some time to come.

Most archives provided some space for researchers to work, even if, as in three cases, it was just a desk in the archivist's office. Only three universities provided no such facility. One of these, a new and small university, said there was not as yet sufficient demand by staff to warrant it. Six provided space for between three and five people. At two universities, research

TABLE 5

SPACE FOR ARCHIVAL COLLECTIONS

\begin{tabular}{lcccc}
\hline \hline & \multicolumn{4}{c}{ Type of University } \\
& Large & Small & Old & New \\
\hline $\begin{array}{l}\text { Adequate } \\
\begin{array}{c}\text { Adequate for the time } \\
\text { being }\end{array}\end{array}$ & 2 & 3 & 2 & 3 \\
$\begin{array}{l}\text { Only just adequate } \\
\text { Inadequate at present but } \\
\quad \begin{array}{l}\text { will soon become } \\
\text { adequate }\end{array}\end{array}$ & 2 & 2 & 1 \\
\begin{tabular}{l} 
Inadequate \\
\hline
\end{tabular} & 2 & 1 & 1 & 1 \\
\end{tabular}

TABLE 6

PERSON TO WHOM ARCHIVIST IS RESPONSIBLE

\begin{tabular}{|c|c|c|c|c|c|}
\hline \multirow[b]{2}{*}{ Year } & \multirow[b]{2}{*}{ Officer } & \multicolumn{4}{|c|}{ Type of University } \\
\hline & & Large & Small & Old & New \\
\hline \multirow[t]{2}{*}{1985} & Registrar & 6 & 6 & 6 & $\frac{6}{6}$ \\
\hline & Librarian & - & 3 & & 3 \\
\hline \multirow[t]{2}{*}{1987} & Registrar & 4 & 6 & 5 & 5 \\
\hline & Librarian & 2 & 3 & 1 & 4 \\
\hline
\end{tabular}

space was shared with the library, which in both cases meant sharing a special room accommodating more than twenty people. The university with the largest archive (Melbourne) was able to provide research facilities for sixteen people. In summary, nine universities (60 percent) provided adequate research space. This situation is similar to that in the United States where 40 percent of institutions reported having no separate room for research. ${ }^{14}$

\section{COLLECTIONS}

In Australia, university policies regarding the types of records to be collected in their archives vary. All keep the records of their central administration. Two do not accept departmental material, in one case due to a lack of space. Another archive keeps all university records, including departmental, but does not actively seek the latter. This archive also retains the records of bodies associated with the university (for example, student societies). In this respect, the Australian situation differs from that in Canada where, Wilson reports, some archives do not collect the records of their own institutions but only those of regional ones. ${ }^{15}$ Eight Australian universities have begun an oral history program related to the university, but none has progressed very far because of a lack of funding.

Whether or not an archive serves only as a repository for its university records or also undertakes a wider research role is also a policy matter, one which may have been determined even before the archive officially came into existence. Five Australian universities keep external records in addition to their own. The archives of three (Newcastle, New England and Wol- 
longong) serve a regional function by keeping records of the local area such as papers relating to the farming community, station records, employee ledgers of local properties, business archives, and trade union archives. One archive, New England, serves as the regional repository for the state archives on a permanent basis. The two oldest universities keep large collections of nonuniversity records. Approximately 25 percent of the holdings of the University of Sydney's archive comprise personal and private papers. A full 83 percent of the collection of the archive at the University of Melbourne consists of such papers together with the records of certain large companies and business organizations which, as has been mentioned, contribute in great measure to the funding of the archive. All five universities, as well as ANU, intend that the resources of their archives be available for research.

\section{"'Discouragement and frustration for archivists are inherent in their re- lationship with university libraries,' according to Wilson."}

\section{CONTROL}

Appropriate arrangements for the control of archives, in particular whether or not archives should be administered by libraries, have long been debated in Australia. Thinking in other countries has varied, too. Some argue for placing the archive under the library, while recognizing the advantages (mainly financial) of central administrative control. ${ }^{16}$ Others argue forcefully against such an arrangement. "Discouragement and frustration for archivists are inherent in their relationship with university libraries, according to Wilson." ${ }^{17}$ In Canada, most archives were situated in and responsible to the library, but the trend in the late 1970 s was to separate them. ${ }^{18}$ In this regard, the situation in Canada may differ from that in the United States where 90 percent of college and uni- versity archives were located in the library, though not all of them were responsible to the library administration. ${ }^{19}$ Nicholas Burckel has stated fairly dispassionately the advantages and disadvantages of both alternatives-placing an archive under the supervision of the university administration and locating it under the library. ${ }^{20}$

In Australia, it has recently been argued, the real debate on the administrative control of archives took place in the 1950 and the arguments put forward at that time by both sides have not changed but have only been reasserted. ${ }^{21}$ Some of the participants in the debate, particularly archivists, were against library control. ${ }^{22}$ Others, like R. C. Sharman, who were in favor at the time, ${ }^{23}$ have since revised their views: "Relationship with a library had its importance in the pioneering days, but these days are now past." 24 By 1979 it could be stated that "the archives institutions and the archive profession in Australia are developing along their own lines and with a distinct identity." 25 The placement of university archives up to 1985 tended to confirm this observation. Since then, however, as indicated in table 6 , responsibility for the archives of two of the oldest and largest universities has been shifted from the administration to the library.

As shown in table 6, in 1985, twelve archivists were reporting to the registrar (or other officer of equal or higher rank in the administration) and only three to the librarian. The three universities that have always had their archivists responsible to the librarian are all small and relatively new. Perhaps it is not strange that two of them, whose archives were established in the 1960 s, elected to place them in the library. The other, however, was not established until the mid-1970s, a fact which, given the widespread discussion that had taken place and the trends that seemed to be emerging, made the choice of library control more surprising. On the other hand, these are the three regional New South Wales universities referred to earlier, which keep community as well as university records in their collections, a factor 
which could well have influenced the choice.

\section{THE FUTURE FOR ARCHIVES}

Given the economic climate of the past few years, the fact that on average a university archive has been established every year for the past ten years or so is encouraging for archivists. It is promising that only four of the nineteen universities under discussion do not yet have one. The tertiary education sector represents an expensive endeavor, and funding for higher education has been scrutinized more and more closely in recent years. Calls for accountability, not just from the government but from the community as a whole, have become more frequent and more vociferous. As the cost of staffing constitutes more than 80 percent of the cost of higher education, the emphasis has been on this much more than on other areas of expenditure. It is significant that no CTEC report since 1979 has mentioned archives.

Government plans to fund institutions within the proposed new system of higher education do not preclude the funding of an archive if a particular institution wishes to do so. The amount of funding, however, is likely to be so low that it will discourage universities from spending scarce resources on archives. As the Canadian survey pointed out, "In Universities . . . archives are seldom seen as central to their operating objectives or to their efficient management. ${ }^{\prime 26}$ If, as seems likely, this comment may be applied equally to the Australian situation, the mooted developments in higher education do not augur well for the creation or further development of archives in Australian universities.

On the other hand, the Australian government has indicated that it will encourage closer cooperation between tertiary education institutions and the private and business sector, a relationship that could include the business community funding some aspects of university operations. One instance of such cooperation which involves archives was described at the University of Melbourne. Whether other Australian universities will decide to adopt this model remains to be seen. Many universities may need to rethink the purpose and function of their archives if the archives are to survive and grow in a less buoyant economic climate. The proposed restructuring of the higher education system in Australia, however, may well create new opportunities for greater flexibility and lead to academic innovations encompassing many areas, including archives.

\section{REFERENCES}

1. Nicholas C. Burckel, "Establishing a College Archives: Possibilities and Priorities," College \& Research Libraries 36:384-92 (Sept. 1975).

2. Ernst Posner, "The College and University Archives in the United States," in Colleges and University Archives: Selected Readings (Chicago: Society of American Archivists, 1979), p.80.

3. Maynard Brichford, "The Illiarch," in Colleges and University Archives, p.19.

4. Ian E. Wilson, "Canadian University Archives," in Colleges and University Archives, p.167.

5. R. C. Sharman, "Archives and Research," in Design for Diversity: Library Services for Higher Education and Research in Australia, ed. Harrison Bryan and Gordon Greenwood (St. Lucia: Univ. of Queensland Pr., 1977), p.227.

6. Brichford, quoted by Annabel Straus, "College and University Archives: Three Decades of Development," College \& Research Libraries 40:435 (Sept. 1979).

7. Wilson, "Canadian University Archives," p.166.

8. Nicholas C. Burckel and J. Frank Cook, "A Profile of College and University Archives in the United States," American Archivist 45:410-28 (Fall 1982).

9. Burckel, "Establishing a College Archives," p.386.

10. Linda J. Henry, "Archival Advisory Committees: Why?," American Archivist 48:317 (Summer 1985).

11. Burckel and Cook, "A Profile," p.426. 
12. Wilson, "Canadian University Archives," p.169.

13. Burckel and Cook, "A Profile," p.426.

14. Ibid., p.422.

15. Wilson, "Canadian University Archives," p.167.

16. For example, Miriam I. Crawford, "Interpreting the University Archives to the Librarian," in Colleges and University Archives, p.58-67.

17. Wilson, "Canadian University Archives," p.169.

18. Ibid., p.174.

19. Burckel and Cook, "A Profile," p.424-25.

20. Burckel, "Establishing a College Archives," p.385.

21. Michael Piggott, "Library Control of Archives: An Historical Debate and its Current Relevance," in Library History in Context: Proceedings of the Third Library History Forum, Sydney 1987 (Kensington, Australia: Univ. of NSW School of Librarianship, 1988).

22. Peter Biskup, "A Case against Library Control of Archives," Australian Library Journal 10:40-41 (Jan. 1961).

23. R. C. Sharman, "Library Control of Archives," Australian Library Journal 9:125-28 (July 1960).

24. Sharman, "Archives and Research," p.238.

25. Greig Tillotson, "Archive-Library Relations in Australia," Australian Library Journal 28:73 (Apr. 1979).

26. Quoted by Burckel and Cook, "A Profile," p.428. 